\title{
BOREALNY BOLKÓW. NOWE BADANIA OBOZOWISK MEZOLITYCZNYCH NAD JEZIOREM ŚWIDWIE
}

\author{
BOREAL BOLKÓW. \\ NEW STUDY OF THE MESOLITHIC CAMP ON ŚWIDWIE LAKE
}

\author{
Tadeusz Galiński \\ Instytut Archeologii i Etnologii Polskiej Akademii Nauk, Ośrodek w Szczecinie \\ ul. Kuśnierska 12/12A, 70-536 Szczecin, Poland \\ t.galinski@iaepan.szczecin.pl
}

\begin{abstract}
New research of the Mesolithic camps in Bolków on Świdwie lake provided rich archaeological evidence, including that related to the oldest settlement of the Maglemose culture. The assemblages appeared in Świdwie lake area around 8800/8700 BP and they suggest connection with western Jutland.
\end{abstract}

KEY WORDS: Boreal, Mesolithic, Bolków, Poland, camps, Maglemose culture, flint tools, bone harpoons.

\section{WSTĘP}

Stanowisko w Bolkowie oznaczone nr 1 [AZP 27-04/31] położone jest $25 \mathrm{~km}$ na północny zachód od Szczecina, w sąsiedztwie jeziora Świdwie, na obszarze Puszczy Wkrzańskiej (ryc. 1). W literaturze przedmiotu znane jest od dawna z wieloletnich badań wykopaliskowych prowadzonych przez Dobrochnę Jankowską w latach 80 . z ramienia Instytutu Prahistorii Uniwersytetu im. Adama Mickiewicza w Poznaniu (Galiński 2009, 2011; Galiński, Jankowska 2006; Jankowska 1980).

Wykopaliska o charakterze weryfikacyjnym i uzupełniającym podjęte przez autora w 2006 r. doprowadziły do odkrycia m.in. niezwykle bogatych śladów osadnictwa mezolitycznego w strefie brzegowej zatorfionej zatoki dawnego jeziora Krynickiego (na szwedzkich mapach z XVII w. figuruje jako czynne jeszcze „Krintz See”), dochodzącej od południa do terasy stanowiska wydłużonym, wąskim ramieniem (ryc. 2). Zbiornik ten o pochodzeniu lodowcowym, wytopiskowym był w okresie późnoplejstoceńskim i w początkach wczesnego holocenu oddzielony od jeziora 


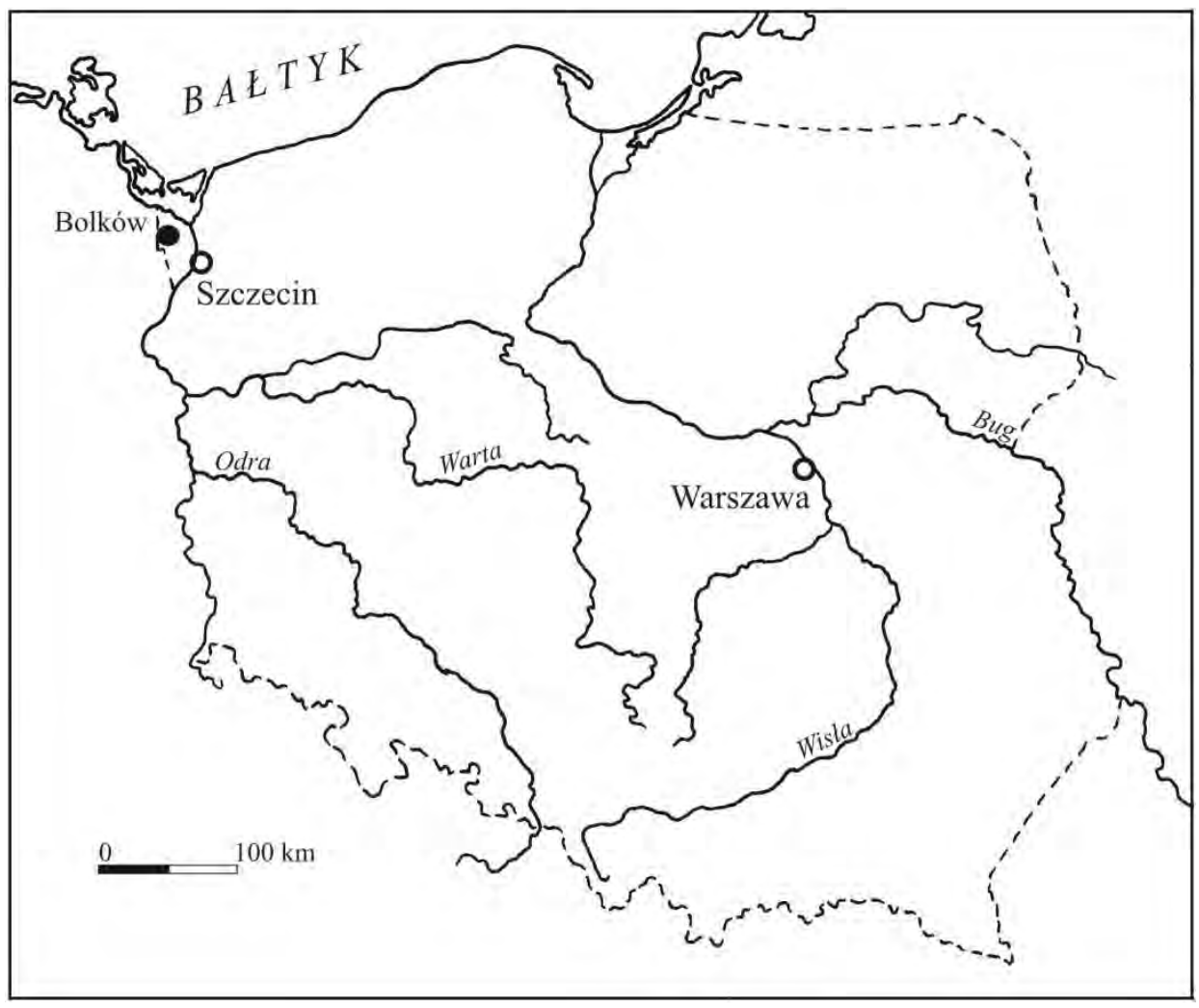

Ryc. 1. Położenie stanowiska Bolków 1 na mapie Polski

Fig. 1. Location of site Bolków 1 on the map of Poland

Świdwie szeroką i lekko wyniesioną terasą piaszczystą. Połączenie obu jezior w jeden rozległy akwen wodny, czego śladem są dzisiejsze torfy przylegające do stanowiska Bolków 1 od strony zachodniej i częściowo od południa, nastąpiło dopiero w okresie atlantyckim w wyniku globalnego i znaczącego podniesienia się wód gruntowych. Na przestrzeni ok. $30 \mathrm{~m}$ wzdłuż pierwotnego, plejstoceńskiego brzegu jeziora widoczne są liczne ślady osadnictwa mezolitycznego.

W latach 2010-2011 przeprowadzono tam prace wykopaliskowe. Pod grubą warstwą osadów torfowych zostały zlokalizowane bogate i dobrze zachowane pozostałości osadnicze z okresu preborealnego i wczesnego borealu. Obok palenisk, jam gospodarczych i śladów po szałasach zarejestrowano liczne wyroby z krzemienia w tym powszechnie znajdowane na stanowiskach mezolitycznych narzędzia służące do obróbki mięsa, kości i skór zwierzęcych (drapacze, rylce, zgrzebła, półtylczaki) oraz groty strzał łuku, tzw. zbrojniki. Poza tym znaleziono przedmioty i narzędzia wykonane z poroża i kości zwierzęcych oraz z drewna. Do spektakularnych znale- 


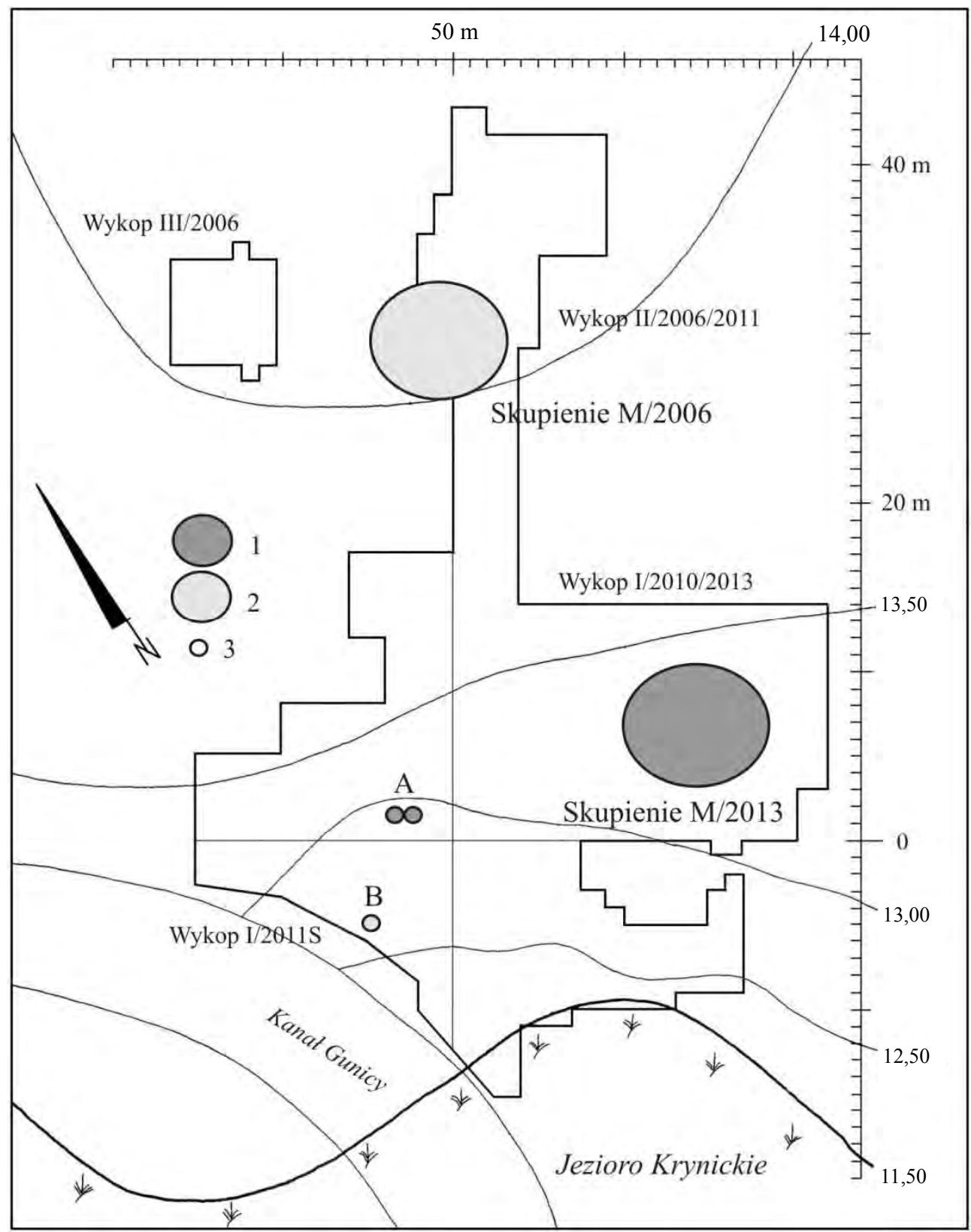

Ryc. 2. Bolków, stan. 1. Lokalizacja obozowisk (skupisk) mezolitycznych w okresie borealnym. Legenda: 1 - obozowisko wczesnoborealne; 2 - obozowisko późnoborealne; 3 - miejsca zalegania harpunów kościanych $\mathrm{nr} 1$ i 3 oraz łopatkowatego przedmiotu rogowego $\mathrm{z}$ ornamentem (A); harpuna $\mathrm{nr} 2$ (B)

Fig. 2. Bolków, site 1. Location of Mesolithic camps (concentrations) in Boreal period. Legend: 1 - early-Boreal camps; 2 - late-Boreal camps; 3 - places of deposition of the bone harpoons No. 1 and 3, as well as spade-shaped ornamented antler object (A); harpoon No. 2 (B) 
zisk w tej grupie należy zaliczyć pierwszy na ziemiach polskich i jeden z kilku znanych w Europie łuk myśliwski wykonany z wiązu (Galiński 2010). Ponadto wydobyto liczne materiały paleobotaniczne - szyszki, łupiny orzechów leszczynowych, żołędzie i inne owoce leśne czy liście różnych roślin i drzew oraz materiały paleozoologiczne - szczątki zwierząt, ptaków i ryb - dające w sumie duże możliwości rekonstrukcji środowiska przyrodniczego, w którym występowało osadnictwo człowieka mezolitycznego.

Ogromne znaczenie tych odkryć dla poznania najstarszych dziejów osadnictwa postglacjalnego w tej części Niżu Europejskiego i kształtowania się obrazu kulturowego $\mathrm{w}$ powiązaniu $\mathrm{z}$ różnorodną aktywnością gospodarczo-społeczną łowców mezolitycznych stworzyły potrzebę kontynuacji oraz znacznego rozszerzenia badań w kierunku interdyscyplinarnym. W latach 2012-2014 zrealizowano projekt badawczy pod kierunkiem autora w ramach Narodowego Programu Rozwoju Humanistyki (Nr 11H 11 018380) pt. „Społeczeństwa łowiecko-zbierackie wczesnego mezolitu w rejonie dolnej Odry". Jego podstawowym założeniem było przeprowadzenie eksploracji pozostałości wszystkich obozowisk łowieckich wczesnego mezolitu położonych w strefie brzegowej dawnego jeziora Krynickiego. W rezultacie została przebadana powierzchnia ponad $400 \mathrm{~m}^{2}$, pozyskano około 8 tys. wyrobów krzemiennych i kamiennych oraz liczne i oryginalne wyroby z surowców organicznych. Odsłonięto pozostałości osadnicze przynajmniej sześciu obozowisk łowieckich - w których m.in. zachowały się resztki dwóch obiektów szałasowych i dwie półziemianki - pochodzące z różnych odcinków okresu preborealnego oraz borealu. Razem stanowią one pełną sekwencję chronologiczno-kulturową osadnictwa wczesnego mezolitu na tym obszarze.

Eksploracjom archeologicznym towarzyszyły badania geologiczne, palinologiczne, paleobotaniczne i dendrologiczne, paleozoologiczne, analizy radiowęglowe oraz badania archeologii eksperymentalnej związane z rekonstrukcją łuków myśliwskich i innych narzędzi oraz przedmiotów użytkowych.

Niniejszy artykuł dotyczy zagadnień związanych z obozowiskami łowieckimi $\mathrm{z}$ okresu borealnego, zlokalizowanymi na platformie terasy i w strefie brzegowej dawnego jeziora Krynickiego, które badane były w latach 2006, 2011 i 2013.

\section{STRATYGRAFIA STANOWISKA}

W obrębie odkrywki II/2006/2011 i połączonego wykopu I/2010/2013 na przestrzeni ok. $30 \mathrm{~m}$ znajdowały się dwa różne układy litostratygraficzne oddające w pełni ukształtowanie wyższej terasy zalewowej względem jeziora w okresach funkcjonowania na tym obszarze osadnictwa oraz paleohistorię rozwoju i zaniku zbiornika. 


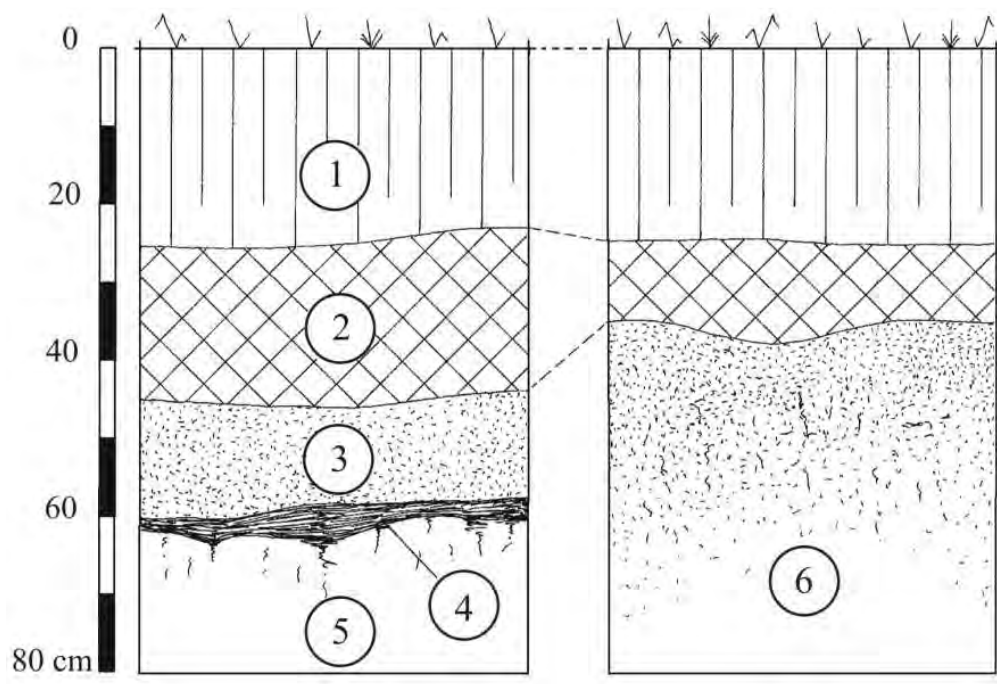

A

B

Ryc. 3. Bolków, stan. 1. Profil zachodni połączonego wykopu I/2010-2013 (A) i profil zachodni wykopu I/2006/2011(B) (objaśnienia do profilów w tekście)

Fig. 3. Bolków, site 1. West profile of joined trenches $\mathrm{I} / 2010-2013$ (A) and west profile of trench $\mathrm{I} / 2006 / 2011$ (B) (explanations for profiles in the text)

Na obszarze odkrywki II/2006/2011, obejmującej fragment najwyżej położonej części platformy terasy, profil zbudowany był zaledwie z trzech warstw. Są to (ryc. 3B):

1) próchnica gleby o miąższości $20 / 27 \mathrm{~cm}$ (warstwa nr 1);

2) soczewki torfu brunatnego mocno zbitego i silnie zapiaszczonego zwłaszcza w górnych poziomach: 20/27-35/50 cm (warstwa $\mathrm{nr} 2$ );

3) żółty piasek gruboziarnisty z licznymi wtrąceniami związków żelazistych w partiach stropowych lub żółtobrązowy piasek z dużym udziałem frakcji gliniastej, budujące strop platformy terasy: poniżej $35 / 50 \mathrm{~cm}$ (warstwa $\mathrm{nr} 6$ ).

Na terenie wykopu I/2010-2013, obejmującego środkową i południową część platformy wyższej terasy zalewowej, profil był nieco bardziej rozbudowany, a tworzyły go następujące poziomy glebowe i warstwy geologiczne (ryc. 3A):

1) próchnica gleby piaszczysto-torfowej o grubości $20 / 30 \mathrm{~cm}$ (warstwa $\mathrm{nr} 1$ );

2) torf brunatny, silnie zapiaszczony w partiach stropowych: $20 / 30-40 / 57 \mathrm{~cm}$ (warstwa nr 2);

3) żółty piasek gruboziarnisty z dużą zawartością związków żelazistych (orszty$\mathrm{nu})$ : 40/57-60/65 cm (warstwa $\mathrm{nr} 3$ );

4) warstwa osadów organicznych w postaci słabo rozłożonego drewna, kory, sprasowanych liści i paproci oraz innych roślin: 60/65-65/72 cm (warstwa nr 4); 


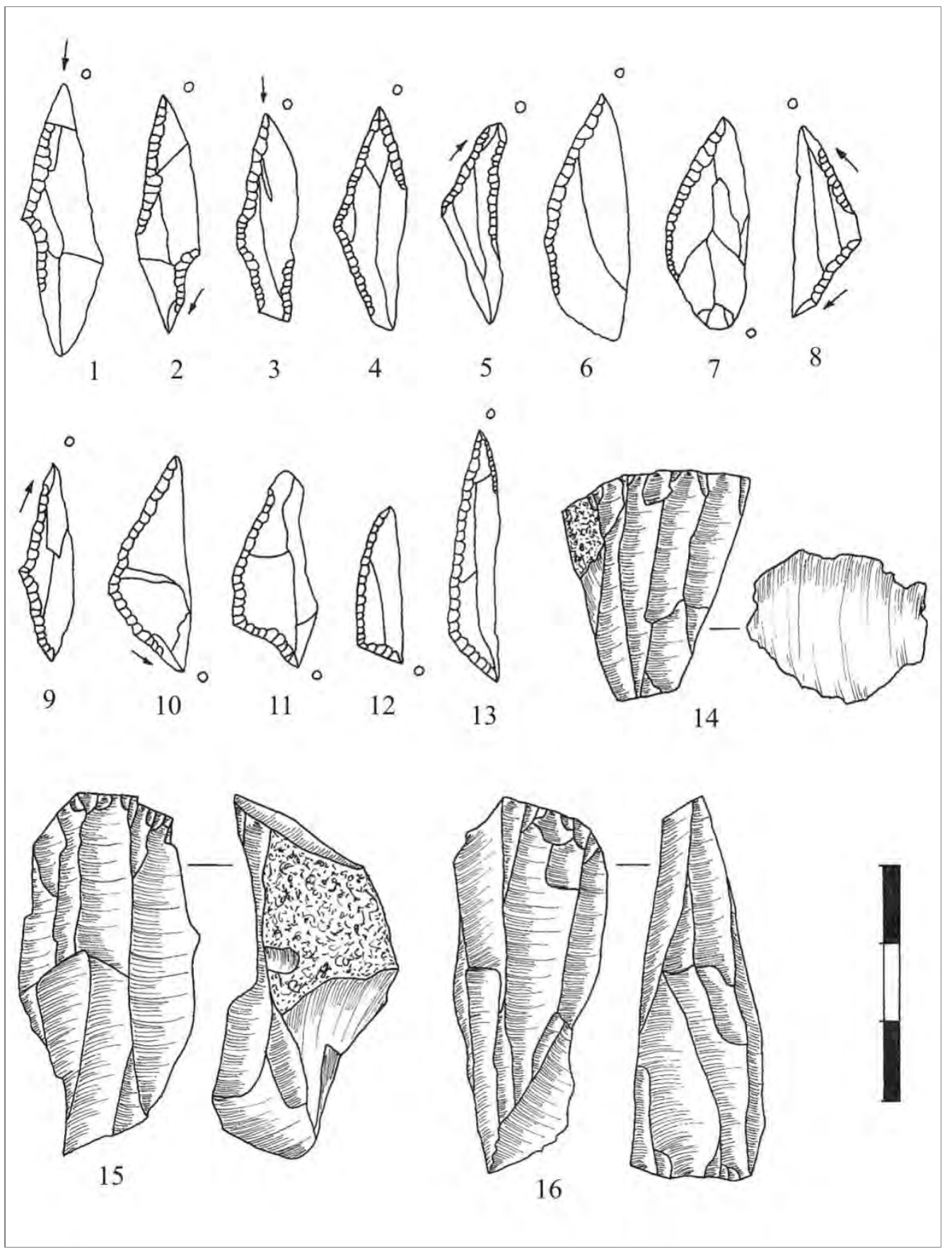

Ryc. 4. Bolków, stan. 1, skupienie M/2013. Wybór narzędzi i rdzeni: 1-13-zbrojniki; 14-16-rdzenie

Fig. 4. Bolków, site 1, concentration M/2013. Selected tools and cores: 1-13 - microliths; 14-16-cores 
5) beżowy lub jasnożółty piasek gruboziarnisty z dużą zawartością związków żelazistych (orsztynu) oraz substancji organicznych - pozostałości roślin wodnych w postaci brązowych plamek - w partiach stropowych: poniżej $60 / 72 \mathrm{~cm}$ (warstwa $\mathrm{nr} 5$ ).

Odkrywki obejmowały fragment południowej części najwyżej wyniesionej, siodełkowato uformowanej platformy terasy oraz znaczny odcinek środkowej i dolnej części terasy zalewowej borealnego Jeziora Krynickiego. Na obszarze tym zlokalizowano pozostałości osadnicze dwóch obszernych skupień mezolitycznych z okresu borealnego: a) obozowisko północne M/2006 położone w południowej części najwyżej wyniesionej platformy terasy (opis profilu nr 1): wyroby krzemienne, kamienne i z surowców organicznych zalegały in situ $\mathrm{w}$ górnych poziomach żółtych i żółtobrązowych piasków budujących strop terasy plejstoceńskiej (warstwa nr 6); b) obozowisko południowe $\mathrm{M} / 2013$ usytuowane na całej szerokości dolnej terasy zalewowej w strefie brzegowej borealnego jeziora Krynickiego (opis profilu $\mathrm{nr}$ 2): pozostałości występowały in situ przede wszystkim w żółtym piasku (warstwa nr 3), rzadziej w stropowych partiach warstwy osadów organicznych (warstwa $\mathrm{nr} 4$ ). Krzemienie i inne wyroby zalegające poniżej, w górnych partiach beżowego piasku (warstwa $\mathrm{nr}$ 5), związane są z osadnictwem starszym - późnoglacjalnym i preborealnym.

W okresie borealnym, jak wynika z analizy profili wykopów na całym obszarze terasy, linia brzegowa zbiornika musiała znacznie przesunąć się w kierunku północnym: prawdopodobnie z poziomicy $12,00-12,50 \mathrm{~m}$ w początkach borealu na wysokość poziomicy $13,50 \mathrm{~m}$ pod koniec tego okresu (ryc. 2). Natomiast w początkach okresu optimum klimatycznego wczesnego holocenu, tj. około 7700 BP (Starkel 1977, s. 90) prawie cały obszar stanowiska, przynajmniej do poziomicy $14,00 \mathrm{~m}$, znalazł się pod wodą atlantyckiego jeziora zalewowego. Oba odsłonięte w wykopach obozowiska borealne położone były odpowiednio w bezpośrednim sąsiedztwie ówczesnej linii wody, od której dzieliła je odległość nie większa niż $12-15 \mathrm{~m}$. Na całym obszarze platformy terasy powierzchnia gruntu była mniej więcej płaska wzdłuż osi wschód-zachód i łagodnie opadała w kierunku południowym, o natężeniu spadku wynoszącym $0,5 \mathrm{~m} / 10 \mathrm{~m}$.

\section{DATOWANIE RADIOWEGLOWE}

Spośród kilkunastu próbek kości zwierzęcych i węgli drzewnych ze stanowiska w Bolkowie, które poddane zostały analizie radiowęglowej 14C, pięć wiąże się z omawianym tu osadnictwem. Są to następujące oznaczenia:

1) próba przepalonych kości zwierzęcych wydobytych z jamy gospodarczej położonej w obrębie skupienia $\mathrm{M} / 2013$ na terenie połączonego wykopu I/2010-2013: 8650 \pm 40 BP [MKL-1870]; 
2) próba węgli drzewnych pobranych ze stropu warstwy organicznej (warstwy

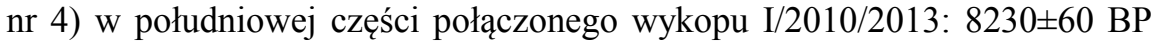
[Gd-3250];

3) próba kości zwierzęcych wydobytych z jamy gospodarczej położonej w obrębie skupienia M/2006 na terenie połączonego wykopu II/2006/2011: $7920 \pm 40$ BP [MKL-1867];

4) próba fragmentu kości - harpuna typu Gniewino (ryc. 9:2) - wydobytej ze stropu beżowego piasku (warstwa $\mathrm{nr} 5$ ) poza skupieniami osadniczymi na terenie wykopu I/2011- 2013, ,S”: 7760 50 BP [MKL-1871];

5) próba fragmentu poroża - przedmiotu ornamentowanego (ryc. 8) - wydobytego ze stropu beżowego piasku (warstwy $\mathrm{nr}$ 5) poza skupieniami osadniczymi na terenie południowo-zachodniej części połączonego wykopu I/2010-2013: 8700 \pm 40 BP [MKL-1872]).

\section{ZESPOLY OSADNICZE}

Podczas badań realizowanych w latach 2006-2013 na terenie wyższej terasy zalewowej jeziora Krynickiego zlokalizowano dwa duże skupienia osadnicze pochodzące $\mathrm{z}$ okresu borealnego. Oba związane są z kompleksem maglemoskim. $\mathrm{Z}$ analizy paleotopograficznej osadnictwa jednoznacznie wynika, że każde $z$ nich położone było w bliskim sąsiedztwie brzegu niewielkiej zatoki ówczesnego zbiornika, oddalając się bądź przybliżając do niego w zależności od poziomu wód i ich zasięgu na obszarze terasy (ryc. 2).

\section{SKUPIENIE M/2013}

Skupienie południowe określone jako M/2013 reprezentuje najstarsze osadnictwo maglemoskie na stanowisku w Bolkowie. Świadczą o tym jednoznacznie zarówno związane z nim oznaczenia analizy radiowęglowej 14C $(8650 \pm 40 \mathrm{BP}$ i $8700 \pm 40 \mathrm{BP}$ ), jak i wyniki analizy paleotopografii obozowisk w powiązaniu z hydrostratygrafią czy typologii grup narzędziowych, wreszcie porównanie z chronologią i lokalizacją obozowisk starszego osadnictwa kompleksu duvensejskiego (Galiński 2014b). Skupienie usytuowane było na dolnej terasie w odległości co najmniej $12 \mathrm{~m}$ od brzegu ówczesnego jeziora, gdzie występowały bardzo korzystne warunki terenowe, dające nieograniczone możliwości lokalizowania dużych, trwałych obozowisk złożonych z wielu jednostek mieszkalnych. Cały obszar obozowiska zajmował powierzchnię ponad $140 \mathrm{~m}^{2}$. Z obserwacji profili w odkrywkach wynika, że zejście do jeziora było na tym odcinku bardzo dogodne, płaskie, w formie plaży, a tuż przy brzegu znajdowała się spora, ponadmetrowa głębia. 

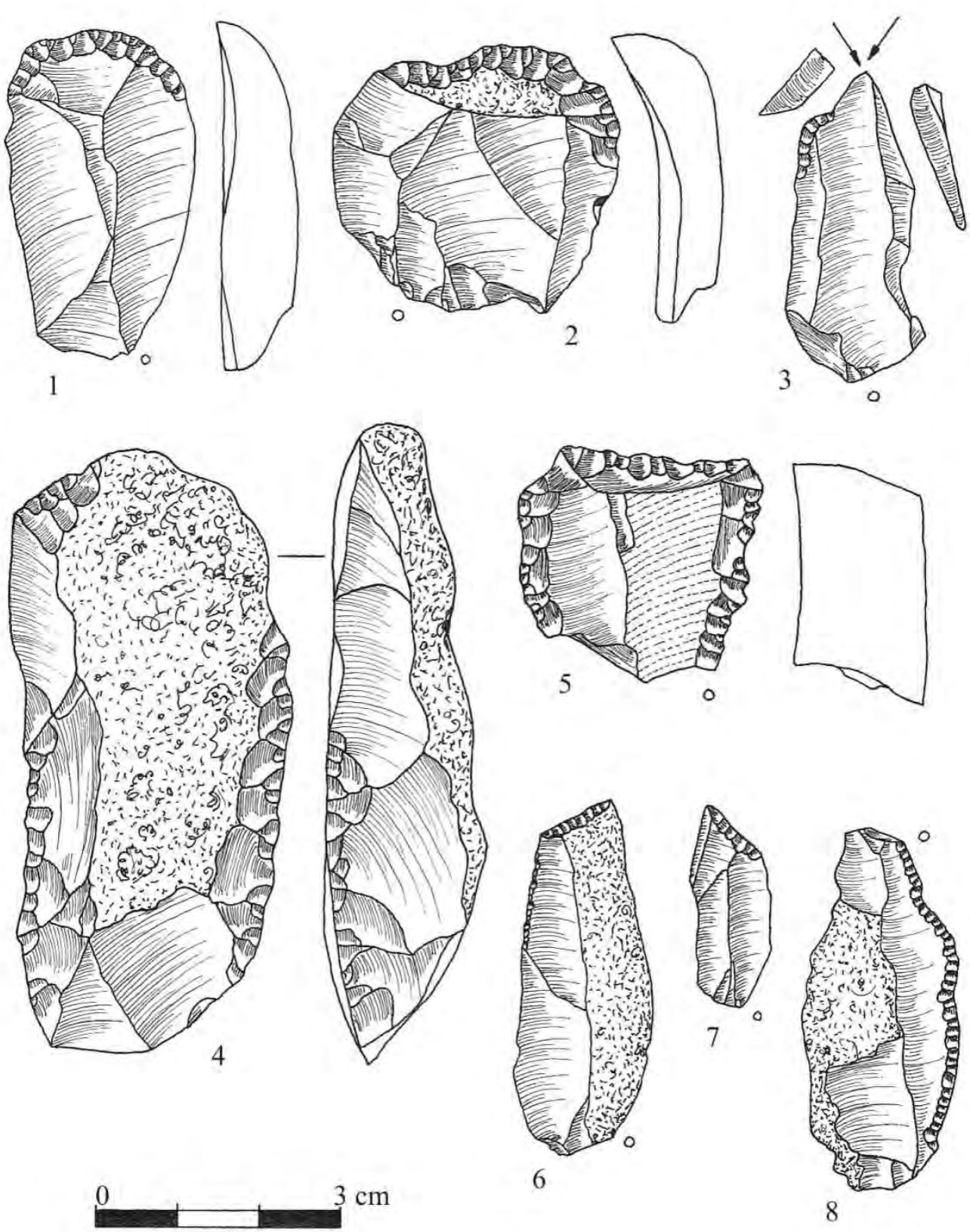

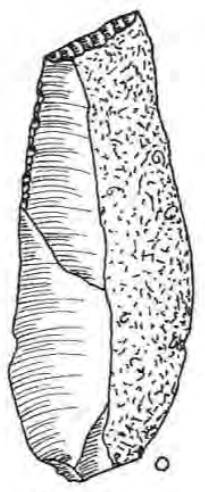

6
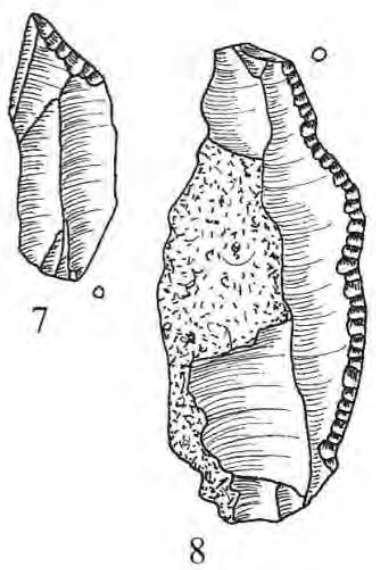

Ryc. 5. Bolków, stan. 1, skupienie M/2013. Wybór narzędzi: 1-2, 5 - drapacze; 3 - rylec; 4 - ciosak; 6-7-półtylczaki; 8 - wiórowiec

Fig. 5. Bolków, site 1, concentration M/2013. Selected tools: 1-2, 5 - end scrapers; 3 - burin; 4 - tranchet; 6-7 - truncated blades; 8 - retouched blade 
$\mathrm{Z}$ rozrzutu materiałów zabytkowych wyłania się układ trzech wyraźnie zaznaczonych koncentracji położonych obok siebie i połączonych wzajemnie rzadziej zalegającymi krzemieniami. Wszystkie krzemienice mają zarysy lekko owalne o średnicach wynoszących odpowiednio: $5,5 \times 5,0 \mathrm{~m} ; 5,0 \times 3,5 \mathrm{~m}$ i 4,5 $\times 4,0 \mathrm{~m}$, oddalone są od siebie od 3 do $5 \mathrm{~m}$. Interpretacja takich układów jest trudna ze względu na zasadniczy problem, jaki wiąże się z pytaniem o wzajemny status tych skupisk wyrobów krzemiennych (Galiński 2011, s. 107-109). Biorąc jednak wszystkie czynniki pod uwagę, wydaje się, iż w tym przypadku najbardziej prawdopodobne jest, że krzemienice tworzą jednolitą strukturę przestrzenną osadnictwa, odzwierciedlającą liczbę koczujących grup w dłuższym okresie.

Oprócz wyrobów krzemiennych i kamiennych ze skupieniem tym wiążą się narzędzia wykonane z surowców organicznych (poroże, kość) oraz przedmioty związane z kulturą duchową. Należą do nich m.in. dwa harpuny kościane (ryc. 9:1, 3) i ornamentowany przedmiot łopatkowaty z poroża łosia (ryc. 8), które zalegały razem poza zwartym zasięgiem skupienia (poza obozowiskiem) nad ówczesnym brzegiem jeziora (ryc. 2:A). Wiek tego znaleziska oznaczony został za pomocą analizy radiowęglowej 14C.

\section{SKUPIENIE M 2006}

Młodsze skupienie osadnictwa maglemoskiego usytuowane było w południowej części najwyżej wniesionego „siodła” piaszczystej platformy terasy, w odległości ok. $15 \mathrm{~m}$ od brzegu ówczesnego Jeziora Krynickiego (ryc. 2). Obszar ten charakteryzował się bardzo korzystnymi warunkami paleotopograficznymi, pozwalającymi na lokalizację dużych i trwałych obozowisk złożonych z wielu jednostek mieszkalnych. Zejście do jeziora było tu dogodne, w formie długiej, piaszczystej plaży, a sam zbiornik tworzył na tym odcinku szeroką zatokę, gdzie płycizna brzegowa zajmowała pas o szerokości przynajmniej kilkunastu metrów. Podobnie jak w przypadku starszego skupienia osadniczego, rozrzut materiałów zabytkowych stanowił układ kilku koncentracji połączonych rzadziej występującymi krzemieniami. W obrębie wykopów znajdowały się dwie krzemienice owalne o średnicach odpowiednio: 4,0 × 3,0 m i 3,5 $\times 3,0 \mathrm{~m}$, oddalone od siebie o 2-3 m. Jednak na podstawie licznych sondaży przeprowadzonych wokół odkrywki wiadomo, że poza obszarem wykopu II/2006/2011 w kierunku zachodnim i południowo-zachodnim położone są kolejne, przynajmniej dwie koncentracje niewątpliwie związane z tym osadnictwem. W sumie są to cztery lub nawet pięć krzemienic połączonych rzadziej występującymi krzemieniami, zajmujących obszar ponad $160 \mathrm{~m}^{2}$. Interpretacja tego układu jest analogiczna do wyżej opisanego skupienia M/2013. 


\section{PRZEMYSL KRZEMIENNY}

\section{Surowiec}

Podstawowym surowcem wykorzystywanym do produkcji narzędzi były szare odmiany krzemienia bałtyckiego pozyskiwane $\mathrm{z}$ bogatych złóż zalegających w okolicznych utworach morenowych Wału Stobniańskiego. Jeszcze dzisiaj dużą obfitość tego surowca widać $\mathrm{w}$ gliniasto-żwirowych kopcach i wałach kemowych położonych w stosunkowo niewielkiej odległości od stanowiska na zachodnich brzegach jeziora Świdwie. Najbardziej poszukiwana była względnie dobrej jakości odmiana o zabarwieniu jednolitym ciemnoszarym. Charakteryzuje się bardzo dobrym połyskiem i mocnym sfalowaniem powierzchni przy odbijaniu. Mieszkańcy obozowisk wykorzystywali stosunkowo niewielkie konkrecje - o średnicy 6-8 cm - najczęściej o kształtach płytowatych i klockowatych, rzadziej owalnych.

W zespole starszym, wczesnoborealnym, wykorzystywano w niewielkim stopniu również krzemień dolnoodrzański. W materiałach stwierdzono obecność dwóch odmian tego surowca: a) dość powszechny krzemień o zabarwieniu brązowym w różnych odcieniach; podejmowane konkrecje były niewielkie, o średnicy do $6 \mathrm{~cm}$, o kształtach bułowatych; b) rzadko spotykana na stanowiskach mezolitycznych lewego brzegu Odry odmiana o zabarwieniu jednolitym czekoladowym. Krzemień ten charakteryzuje się bardzo dobrymi właściwościami łupania. Wykorzystywane konkrecje miały kształty płytowate i były znacznie większych rozmiarów (do $10 \mathrm{~cm}$ średnicy).

\section{Rdzenie}

Obecne są prawie wszystkie typy i formy rdzeni znane $\mathrm{z}$ wcześniejszych okresów epoki kamienia (ryc. 4:14-16; ryc. 6:1-4). W zespole starszym najbardziej popularne były rdzenie dwupiętowe wspólnoodłupniowe typu mazowszańskiego, natomiast $\mathrm{w}$ zespole młodszym rdzenie jednopiętowe klockowate (tabela 1). Jednak najbardziej charakterystyczną grupę stanowią tu różne odmiany rdzeni dwupiętowych rozdzielnoodłupniowych, wśród których wyróżnia się formy dwupiętowe o piętach naprzeciwległych i odłupniach stykających się bokami (ryc. 4:16); rdzenie o piętach i odłupniach naprzeciwległych (ryc. 6:2); rdzenie o piętach prostopadłych i odłupniach prostopadłych jednopłaszczyznowo (ryc. 6:3); wreszcie, rdzenie o piętach i odłupniach ustawionych prostopadle $\mathrm{w}$ różnych płaszczyznach (ryc. 6:4). Zbliżone do nich morfologicznie są dość oryginalne na stanowiskach mezolitycznych formy wielopiętowe o zmiennej orientacji, w których kolejne pięty sytuowane były na wcześniej eksploatowanych odłupniach ustawionych zazwyczaj prostopadle.

Wśród rdzeni dwupiętowych wspólnoodłupniowych i rdzeni jednopiętowych, które z reguły stanowiły formę wyjściową eksploatacji półsurowca, spotyka się za- 


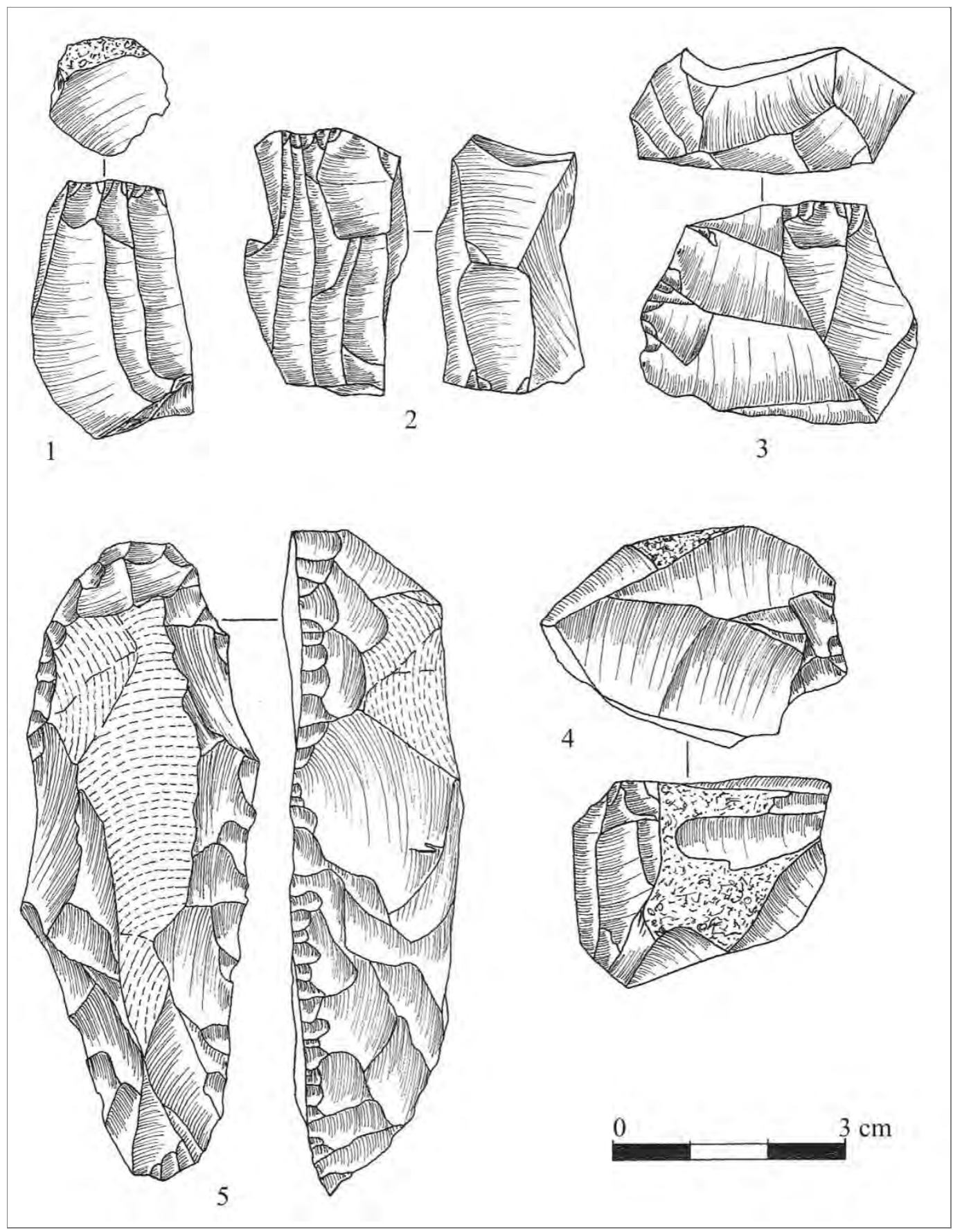

Ryc. 6. Bolków, stan. 1, skupienie M/2006. Wybór rdzeni i narzędzi: 1-4-rdzenie; 5 -pik

Fig. 6. Bolków, site 1, concentration M/2006. Selection of cores and tools: 1-4-cores; 5 - pick 
Tabela 1. Typy rdzeni występujące w inwentarzach poszczególnych skupień osadniczych

Table 1. Types of cores within inventories of particular settlement concentrations

\begin{tabular}{|l|rl|rl|}
\hline \multicolumn{1}{|c|}{ Typy rdzeni } & \multicolumn{2}{|c|}{ Skupienie M/2013 } & \multicolumn{2}{c|}{ Skupienie M/2006 } \\
\hline Dwupiętowe wspólnoodłupniowe & 14 & $(13,73 \%)$ & 7 & $(11,11 \%)$ \\
\hline Dwupiętowe rozdzielnoodłupniowe & 8 & $(7,84 \%)$ & 9 & $(14,29 \%)$ \\
\hline Jednopiętowe płaskie & 5 & $(4,90 \%)$ & 9 & $(14,29 \%)$ \\
\hline Jednopiętowe klockowate & 8 & $(7,84 \%)$ & 13 & $(20,63 \%)$ \\
\hline Jednopiętowe stożkowate i baryłkowate & 12 & $(11,76 \%)$ & 2 & $(3,17 \%)$ \\
\hline Wielopiętowe i ze zmianą orientacji & 13 & $(12,75 \%)$ & 11 & $(17,46 \%)$ \\
\hline Nieokreślone & 42 & $(41,18 \%)$ & 12 & $(19,05 \%)$ \\
\hline Razem & 102 & $(100 \%)$ & 63 & $(100 \%)$ \\
\hline
\end{tabular}

prawę przygotowawczą pięt, boków i tyłów u ok. 35\% okazów. Najczęściej jednak przygotowanie rdzenia ograniczało się tylko do uformowania pięty i wyrównania powierzchni przyszłej odłupni, rzadziej także do zaprawy boków. W materiałach obu skupień widoczna jest wyraźna przewaga pięt przygotowanych $(49,1-53,7 \%)$ nad zaprawianymi (40,3-42,1\%), z niewielkim udziałem pięt naturalnych $(6,0-8,8 \%)$.

Pod względem charakteru odłupni wyraźną przewagę mają rdzenie wiórowoodłupkowe $(40,0-52,9 \%)$ nad wiórowymi $(28,3-39,2 \%)$, przy relatywnie bardzo wysokim wskaźniku rdzeni wiórkowych $(3,9-21,7 \%)$ i niewielkim udziale form odłupkowych $(3,9-10 \%)$.

Rdzenie odnalezione na stanowisku charakteryzują się dużą zmiennością wielkości i proporcji, w zależności od stopnia wykorzystania masy surowcowej w poszczególnych egzemplarzach. Wiele okazów ma charakter maksymalnie wyeksploatowanych i ich wysokość wynosi zaledwie 2,2-3,2 cm. Wysokość wszystkich rdzeni zawarta jest $w$ przedziale $2,2-6,0 \mathrm{~cm}$, ze średnią $3,4 \mathrm{~cm}$.

\section{Pólsurowiec}

W skupieniach zalegały duże ilości nagromadzonych odpadów produkcyjnych oraz fragmentów półsurowca, w tym najwięcej odłupków. Toteż pod względem ogólnej struktury technologicznej oba inwentarze formalnie charakteryzują się niewielką przewagą grupy eksploatacji odłupkowej nad grupami eksploatacji wiórowej i wiórkowej. Do wyrobu narzędzi wykorzystywane były jednak przede wszystkim wióry $(64,1-67,1 \%)$, w dużo mniejszym stopniu odłupki $(15,4-18,2 \%)$ oraz wiórki $(8,0-11,5 \%)$. Narzędzia rdzeniowe wykonano bezpośrednio z fragmentów rozbitych konkrecji $(6,8-9,0 \%)$.

Wióry produkowane były w trzech kategoriach metrycznych: a) wąskie, o szerokości 0,9-1,2 cm; b) średnie, o szerokości 1,3-1,9 cm - tych jest zdecydowanie 
najwięcej; c) szerokie, powyżej $1,9 \mathrm{~cm}$. Te ostatnie osiągały maksymalnie $2,8 \mathrm{~cm}$ szerokości. Były to wióry o długości do $7,5 \mathrm{~cm}$, głównie jednak krótkie i średnie, mierzące 3,2-4,7 cm. Standardowy wiór miał długość 4,5 cm i szerokość 1,7 cm. Wiórki były natomiast zarówno wąskie $(0,5 \mathrm{~cm})$, jak i szerokie $(0,7-0,8 \mathrm{~cm})$, przy czym te pierwsze (styl technologiczny C) wystąpiły tylko w zespole młodszym i są dość krótkie (do 3,5 cm). Pod względem stylistycznym półsurowiec ten reprezentuje styl technologiczny A i C (Galiński 2002, s. 65-67, 69-71).

Odłupki wykorzystywane do produkcji narzędzi miały parametry zbliżone do przeciętnych wiórów. Ich wielkość wynosiła od 1,6 do $7 \mathrm{~cm}$ średnicy, przy czym najbardziej popularne były okazy małe i średnie, mierzące $3-3,8 \mathrm{~cm}$.

\section{NARZĘDZIA}

Do najważniejszych narzędzi w badanych zespołach należą zbrojniki, rylce, drapacze, półtylczaki oraz ciosaki i piki. Towarzyszą im nieliczne zgrzebła, pazury, narzędzia zębate, wiórowce, narzędzia wnękowe oraz inne. Pod względem ogólnej struktury grup narzędziowych zespoły te prezentują jeden model, w którym obok najliczniejszej grupy zbrojników - co jest typowe dla wszystkich bogatszych inwentarzy mezolitycznych - rylce zdecydowanie przeważają nad drapaczami i półtylczakami, ze stosunkowo niskim udziałem grupy ciosaków i pików oraz pozostałych grup narzędziowych (tabela 2). Taki układ w pełni oddaje podomowy charakter obozowisk, w których wykonywane były wszystkie podstawowe czynności związane z gospodarką łowiecko-zbieracką.

Tabela 2. Ogólna struktura grup narzędziowych w poszczególnych inwentarzach

Table 2. General structure of tool groups in particular inventories

\begin{tabular}{|l|rl|rl|}
\hline \multicolumn{1}{|c|}{ Rodzaje narzędzi } & \multicolumn{2}{c|}{ Skupienie M/2013 } & \multicolumn{2}{c|}{ Skupienie M/2006 } \\
\hline Drapacze & 7 & $(8,97 \%)$ & 9 & $(10,23 \%)$ \\
\hline Zgrzebła & 1 & $(1,28 \%)$ & 1 & $(1,14 \%)$ \\
\hline Rylce & 16 & $(20,51 \%)$ & 20 & $(22,73 \%)$ \\
\hline Półtylczaki & 6 & $(7,69 \%)$ & 12 & $(13,64 \%)$ \\
\hline Pazury & \multicolumn{2}{c|}{-} & 4 & $(4,55 \%)$ \\
\hline Narzędzia zębate & 3 & $(3,85 \%)$ & 1 & $(1,14 \%)$ \\
\hline Wiórowce & 2 & $(2,56 \%)$ & 2 & $(2,27 \%)$ \\
\hline Narzędzia wnękowe & 3 & $(3,85 \%)$ & 5 & $(5,68 \%)$ \\
\hline Ciosaki i piki & 4 & $(5,13 \%)$ & 5 & $(5,68 \%)$ \\
\hline Zbrojniki & 35 & $(44,87 \%)$ & 28 & $(31,82 \%)$ \\
\hline Inne formy & 1 & $(1,28 \%)$ & 1 & $(1,14 \%)$ \\
\hline Razem & 78 & $(100 \%)$ & 88 & $(100 \%)$ \\
\hline
\end{tabular}




\section{Drapacze}

Udział drapaczy w ogólnej strukturze narzędziowej inwentarzy jest średni i kształtuje się na poziomie 9,0-10,2\%. Pod względem typologicznym to 4 różne kategorie (Galiński 2002, s. 20-43). Najbardziej powszechne były drapacze smukłe i krępe, duże, średnie, małe i mikrolityczne o różnie ukształtowanych drapiskach (głównie łukowych) i o surowych bokach (kategoria 90 - ryc. 5:1; ryc. 7:11). Stanowią one 50\% wszystkich okazów odnalezionych w badanych skupieniach. Następne w kolejności są drapacze krótkie o surowych bokach (kategoria 98 - ryc. 5:2; ryc. 7:12). Ponadto obecne są drapacze smukłe i krępe o bokach łuskanych (kategoria 91) oraz drapacze tarnowiańskie krótkie o łuskanych bokach (kategoria 99 - ryc. 5:5). Ich łączny udział w grupie narzędzi jest jednak niewielki i wynosi $18,8 \%$. Drapacze wykonywane były W większości z wiórów $(68,8 \%)$. Są małe $(43,8 \%)$, średnie $(31,3 \%)$ i mikrolityczne (25\%). W proporcjach krępe (50\%) i krótkie (43,8\%), rzadziej smukłe $(6,3 \%)$.

\section{Rylce}

Grupa ta dominuje w obu badanych inwentarzach, zajmując odpowiednio 20,5\% i 22,7\% udziału, i są w niej praktycznie wszystkie znane w mezolicie kategorie tych wyrobów (ryc. 5:3; ryc. 7:13-14, 16). Rylce węgłowe minimalnie przeważają nad rylcami klinowymi $(32,4 \%$ wobec $29,4 \%)$, ze znaczącym udziałem rylców łamańców $(14,7 \%)$, jedynaków podłużnych $(14,7 \%)$ i zwielokrotnionych $(8,8 \%)$. Najbardziej popularne były rylce klinowe środkowe i zboczone (kategoria 106 - ryc. 5:5; ryc. 7:13), następnie rylce węgłowe boczne (kategoria 109), łamańce (kategoria 111) i jedynaki podłużne (kategoria 113). Przeważają okazy sporządzone z wiórów $(52,9 \%)$ nad odłupkowymi $(41,2 \%)$, z niewielkim udziałem okazów wykonanych bezpośrednio z rozbitych konkrecji lub z innych narzędzi rdzeniowych $(5,9 \%)$. Na licznych rylcach są ślady wielokrotnych przeróbek ostrzy, które w ponad $41 \%$ są szerokowierzchołkowe $(1>0,9 \mathrm{~cm})$.

\section{Półtylczaki}

Zarejestrowano tylko dwie kategorie: a) półtylczaki o półtylcach skośnych; b) półtylczaki poprzeczne. Te pierwsze zdecydowanie dominują, stanowiąc aż $88,9 \%$ udziału w badanych inwentarzach (ryc. 5: 6-7; ryc. 7:17). Półtylce mają proste, faliste i wygięte, rzadziej wgięte, zazwyczaj 3/4 strome i półstrome, wysokie. Narzędzia te wykonane zostały głównie $\mathrm{z}$ wiórów $(83,3 \%)$, z wiórków $(11,1 \%)$ i z drobnych wióroodłupków (5,6\%). Posłużyły do tego głównie wióry średnie o szerokości 1,3-1,9 cm w zespole starszym $(66,7 \%)$ oraz wióry wąskie o szerokości $1,1-1,2 \mathrm{~cm}$ w zespole młodszym (55,6\%). 

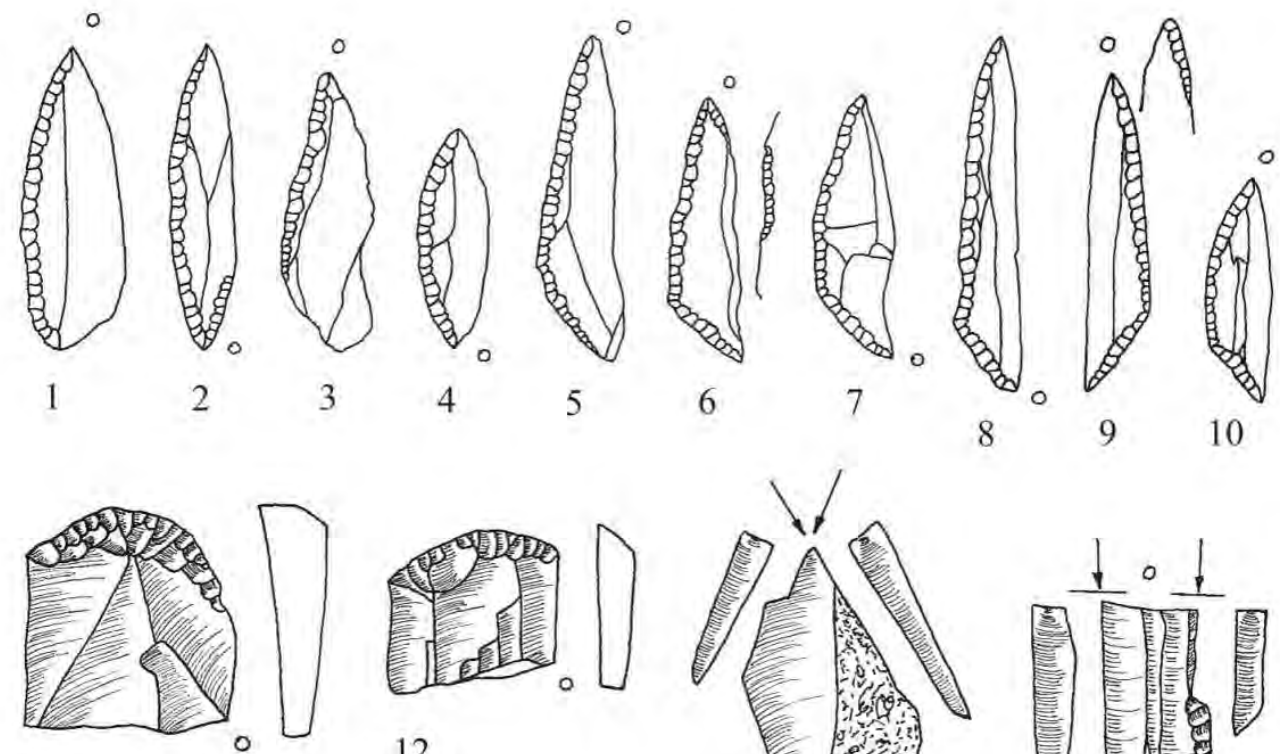

11

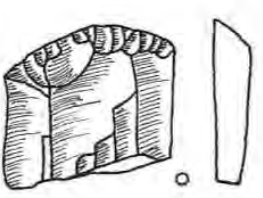

12

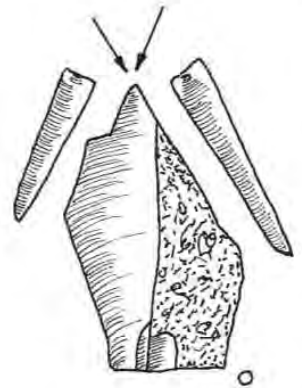

13

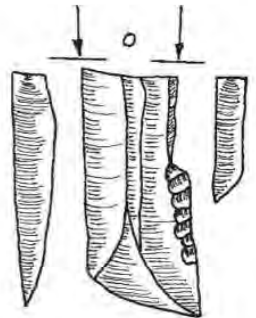

14
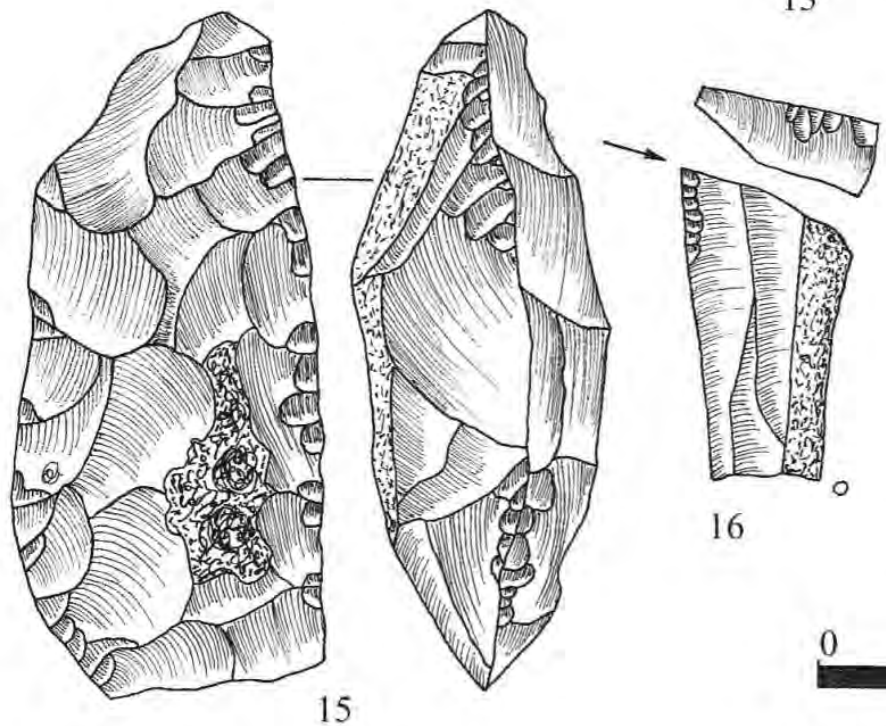

16

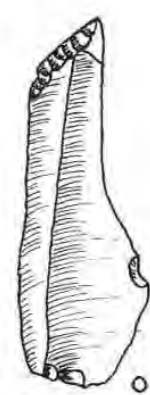

17

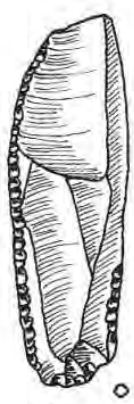

18

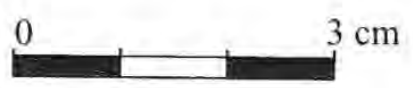

Ryc. 7. Bolków, stan. 1, skupienie M/2006. Wybór narzędzi: 1-10 - zbrojniki; 11-12 - drapacze; 13-14, 16 - rylce; 15 - ciosak; 17 - półtylczak; 18 - wiórowiec

Fig. 7. Bolków, site 1, concentration M/2006. Selected tools: 1-10-microliths; $11-12$ end scrapers; 13-14, 16 - burins; 15 - tranchet; 17 - truncated blade; 18 - retouched blade 


\section{Ciosaki i piki}

Znaleziono duże i średnie $(8,5-6 \mathrm{~cm})$ ciosaki rdzeniowe o ostrzach łukowych formowanych jednym odbocznym uderzeniem lub serią drobnych odbić $\mathrm{z}$ różnych kierunków (ryc. 5:4) oraz o ostrzach prostych formowanych serią drobnych odbić (ryc. 7:15); w przekrojach poprzecznych są rombowate lub częściej - trapezowate. Ponadto obecne są duże i masywne piki podobne do ciosaków (ryc. 6:5).

\section{Zbrojniki}

Grupa ta zawiera wyjątkowo duże bogactwo form (tab. 3). Znaleziono łącznie aż 20 różnych kategorii, w tym wszystkie zaliczane do grupy narzędzi podstawowych i charakterystycznych w zespołach kompleksu wczesnomaglemoskiego (Galiń-

Tabela 3. Frekwencja różnych kategorii zbrojników w badanych zespołach

Table 3. Frequency of various categories of microliths in studied assemblages

\begin{tabular}{|c|c|c|c|c|}
\hline Kategorie zbrojników & \multicolumn{2}{|c|}{$\begin{array}{c}\text { Skupienie } \\
\mathrm{M} / 2013\end{array}$} & \multicolumn{2}{|c|}{$\begin{array}{c}\text { Skupienie } \\
\mathrm{M} / 2006\end{array}$} \\
\hline Jednozadziorce (1) & 1 & $(2,86 \%)$ & 1 & $(3,57 \%)$ \\
\hline Tylczaki złamane w półtylec (2) & & - & 1 & $(3,57 \%)$ \\
\hline Tylczaki z podciętą retuszowaną podstawą (5) & 4 & $(11,43 \%)$ & 2 & $(7,14 \%)$ \\
\hline Tylczaki rombowate $(6)$ & 2 & $(5,71 \%)$ & & - \\
\hline Tylczaki z pazurowatym wierzchołkiem (8) & 3 & $(8,57 \%)$ & & - \\
\hline Ostrza typu Broxbourne (9) & 1 & $(2,86 \%)$ & & - \\
\hline Tylczaki łukowe (14) & 4 & $(11,43 \%)$ & 2 & $(7,14 \%)$ \\
\hline Tylczaki pełnołukowe (15) & 1 & $(2,86 \%)$ & 2 & $(7,14 \%)$ \\
\hline Tylczaki maglemoskie (16) & 4 & $(11,43 \%)$ & 1 & $(3,57 \%)$ \\
\hline Półtylczaki Komornica (17) & 2 & $(5,71 \%)$ & 1 & $(3,57 \%)$ \\
\hline Półtylczaki trapezowato zdwojone (18) & 2 & $(5,71 \%)$ & & - \\
\hline Ostrza typu Creswell (19) & 1 & $(2,86 \%)$ & & - \\
\hline Trójkąty nierównoboczne rozwartokątne o małym boku długim (23) & 2 & $(5,71 \%)$ & 7 & $(25,00 \%)$ \\
\hline Trójkąty łukowe (24) & 2 & $(5,71 \%)$ & 2 & $(7,14 \%)$ \\
\hline Trójkąty nierównoboczne rozwartokątne o małym boku krótkim (25) & & - & 3 & $(10,71 \%)$ \\
\hline Trójkąty małe wąskie rozwartokątne o małym boku krótkim (28) & & - & 1 & $(3,57 \%)$ \\
\hline Trójkąty małe nierównoboczne z pazurowatym wierzchołkiem (31) & & - & 1 & $(3,57 \%)$ \\
\hline Trójkąty duże nierównoboczne z pazurowatym wierzchołkiem (32) & 1 & $(2,86 \%)$ & 1 & $(3,57 \%)$ \\
\hline Wiórki z dwoma półtylcami, trapezowate (41) & 1 & $(2,86 \%)$ & 1 & $(3,57 \%)$ \\
\hline Ostrza typu Vig (50) & 1 & $(2,86 \%)$ & & - \\
\hline Fragmenty nieokreślone & 3 & $(8,57 \%)$ & 2 & $(7,14 \%)$ \\
\hline Razem & 35 & $(100 \%)$ & 28 & $(100 \%)$ \\
\hline
\end{tabular}




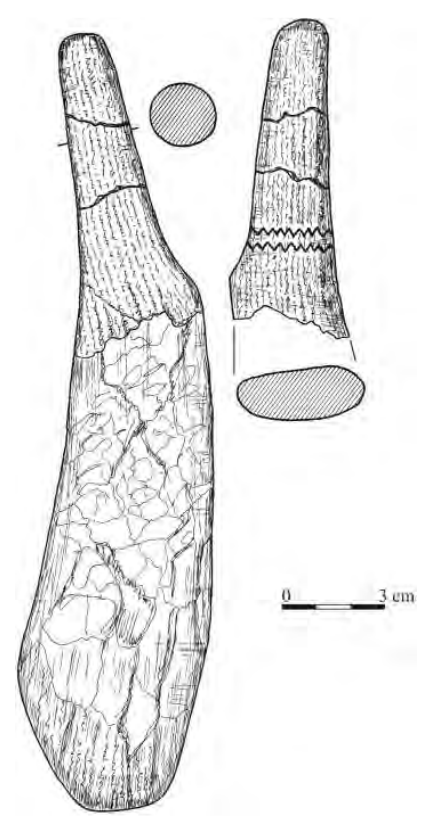

Ryc. 8. Bolków, stan. 1. Przedmiot rogowy zdobiony ornamentem rytym

Fig. 8. Bolków, site 1. Antler object decorated with an incised ornament

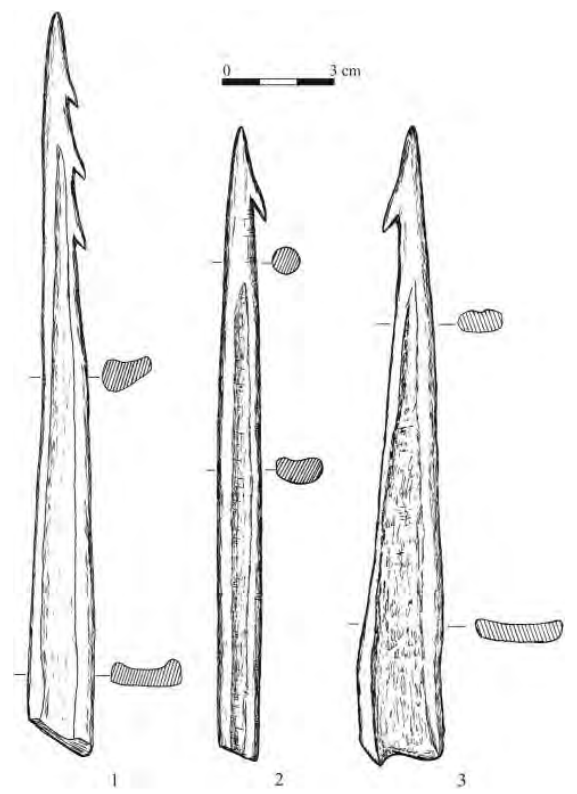

Ryc. 9. Bolków, stan. 1. 1-3 - harpuny kościane

Fig. 9. Bolków, site 1. 1-3-bone harpoons 
ski 2002, s. 202-205). W skupieniu M/2013 najliczniejsze są tylczaki z podciętą retuszowaną podstawą (kategoria 5; ryc. 4:3), tylczaki łukowe (kategoria 14; ryc. 4:6), tylczaki maglemoskie (kategoria 16 ; ryc. 4:7) oraz tylczaki z pazurowatym wierzchołkiem (kategoria 8; ryc. 4:4). Natomiast w skupieniu M/2006 dominują trójkąty nierównoboczne rozwartokątne o małym boku długim (kategoria 23) oraz duże trójkąty nierównoboczne rozwartokątne o małym boku krótkim (kategoria 25).

Dotychczasowe badania wskazują, że frekwencja określonych form zbrojników jest istotnym wyznacznikiem chronologicznym w obrębie poszczególnych ugrupowań kulturowych. W inwentarzach maglemoskich frekwencja ta składa się na wzajemny stosunek grupy tylczaków do grupy trójkątów i obecność mniej lub bardziej licznych kategorii stanowiących styl technologiczno-typologiczny C. Inwentarze z dużym udziałem form tylcowych, brakiem lub mniejszym udziałem trójkątów oraz elementów stylu $C$ należą do najstarszych. Prawidłowość ta znajduje potwierdzenie również w naszych inwentarzach. Zespół starszy M/2013, datowany za pomocą analizy radiowęglowej 14C na pierwszą połowę borealu (około 8700/8600 BP), charakteryzuje się bardzo wysokim wskaźnikiem tylczaków, wśród których - oprócz wyżej wymienionych - znalazły się charakterystyczne jednozadziorce (ryc. 4:1), tylczaki rombowate (ryc. 4:2) czy ostrza typu Broxbourne (ryc. 4:5). Ich stosunek do grupy trójkątów wynosi $4: 1(62,5 \%$ do $15,6 \%)$. Nieobecne są elementy technologiczno-typologiczne stylu C.

W zespole młodszym $\mathrm{M} / 2006$, datowanym na schyłek okresu borealnego i początek Atlantyku (8200-7900 BP), stosunek ten wynosi 3:5 (34,6\% do 57,7\%), a grupa trójkątów reprezentowana jest - poza najliczniejszymi - przez trójkąty łukowe (ryc. 7:7, 10) oraz małe i duże trójkąty $\mathrm{z}$ pazurowatym wierzchołkiem (ryc. 7:6, 9). Ponadto występują elementy typologiczne stylu $\mathrm{C} w$ postaci wiórkowych zbrojników półtylcowych (kategoria 41) i małych, wąskich trójkątów rozwartokątnych o małym boku krótkim (kategoria 28).

Narzędzia wykonywane były głównie $\mathrm{z}$ wąskich wiórów i z szerokich wiórków, wyjątkowo $z$ drobnych odłupków. $Z$ reguły charakteryzują się 3/4 stromym, zatępiającym retuszem jednokierunkowym. Przy ich produkcji stosowana była na dużą skalę technika rylcowcza, a płaskie negatywy przy wierzchołkach - w przeciwieństwie do tradycji duvensejskiej - zazwyczaj nie były załuskiwane.

\section{NARZĘDZIA KAMIENNE}

Oprócz licznych tłuczków, gładzików i podkładek wykorzystywanych w produkcji różnego typu narzędzi krzemiennych i narzędzi z surowców organicznych w obozowisku M/2013 znalazły się niezwykle oryginalne, rzadko spotykane na stanowiskach mezolitycznych inne narzędzia kamienne. Należy do nich przede wszystkim ciosak o szerokim, prostym ostrzu i rombowatym przekroju poprzecznym, wyko- 


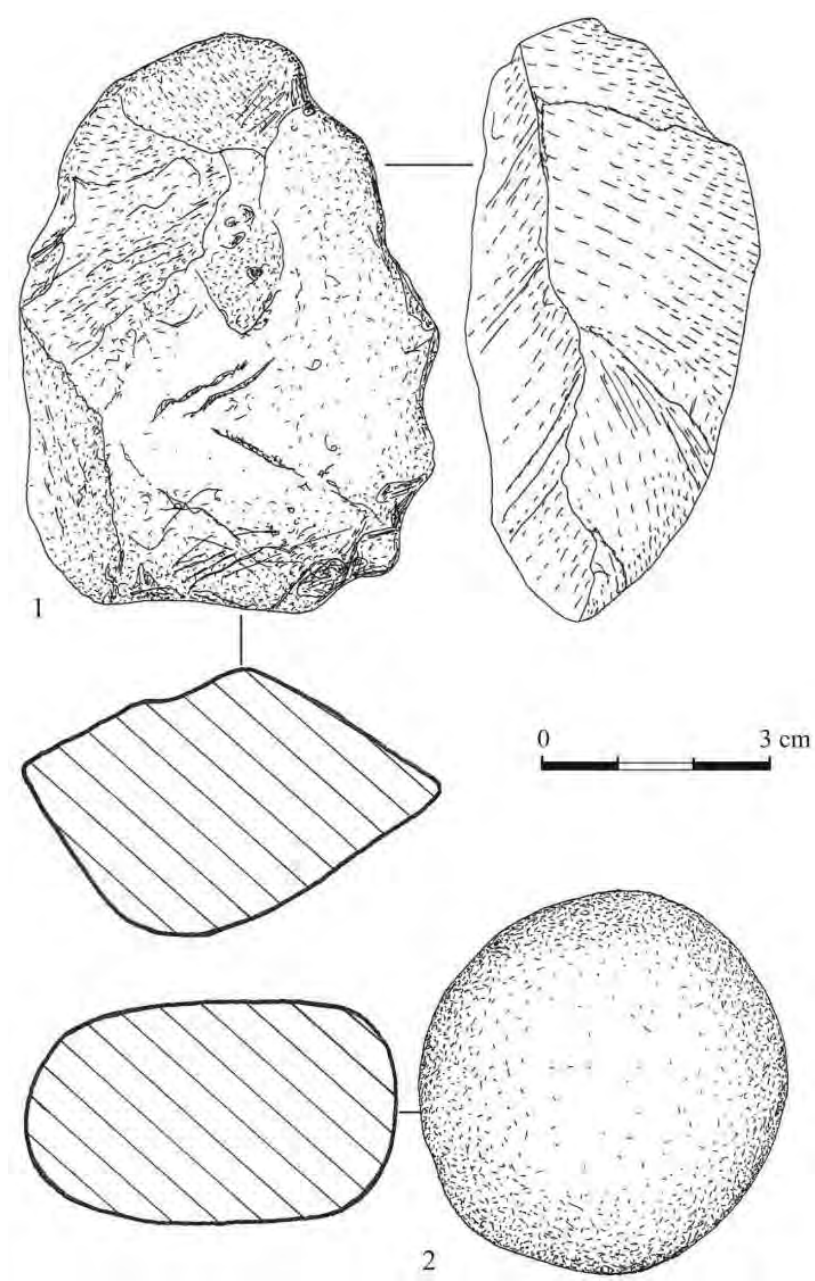

Ryc. 10. Bolków, stan. 1, skupienie M/2013. Narzędzia kamienne: 1 - ciosak; 2 - pocisk procy sznurkowej

Fig. 10. Bolków, site 1, concentration M/2013. Stone tools: 1 - tranchet; 2 - bullet of the string sling

nany z różowego granitu (ryc. 10:1). Ma on wymiary: $7,2 \times 5,2 \times 3,5 \mathrm{~cm}$. Pod względem wielkości i kształtów okaz ten niczym nie różni się od ciosaków krzemiennych. Opracowany został techniką rdzeniową i częściowo wygładzony.

Inny typ narzędzi granitowych stanowią pociski do procy sznurkowej zwanej też frygą, znalezione w obrębie obu skupień osadniczych. Przedmioty te mają kształty koliste i owalne, mocno spłaszczone, obustronnie wygładzone, a ich średnice wynoszą od 3 do $5 \mathrm{~cm}$ (ryc. 10:2). Proca sznurkowa, jak pokazują to badania także innych obozowisk łowieckich na stanowisku w Bolkowie (Galiński 2014b), była bronią miotaną dość powszechnie stosowaną przez łowców mezolitycznych. 
Na terenie obozowiska M/2013 zarejestrowano ciekawy przykład ilustrujący sposób wykonywania kamiennych pocisków procy. Znaleziono tam dwa, prawdopodobnie porzucone, półwytwory, które w fazie wstępnej były formowane do odpowiednich kształtów i wielkości według takich samych reguł techniki rdzeniowej, jakie stosowano w produkcji narzędzi krzemiennych. Zabytki te wyglądają jak granitowe rdzenie, które były skracane bezpośrednim uderzeniem za pomocą twardszego tłuka. Końcowy etap opracowania polegał na dokładnym zagładzeniu powierzchni.

\section{WYROBY Z SUROWCÓW ORGANICZNYCH}

$\mathrm{Z}$ osadnictwem zespołów maglemoskich związane są trzy harpuny kościane wydobyte w południowo-zachodniej części połączonego wykopu I/2010-2013 oraz na terenie odkrywki I/2011-2012 „S”. Narzędzia znajdowały się w pewnym oddaleniu od obozowisk, nad brzegiem płytkiej zatoki ówczesnego borealnego jeziora Krynickiego oraz jeszcze dalej, na przybrzeżnej płyciźnie tego zbiornika (ryc. 2:A-B). Dwa z nich (ryc. 9:1, 3) zalegały razem zagrzebane w mule na brzegu zatoki, w sąsiedztwie łopatkowatego przedmiotu rogowego $\mathrm{z}$ ornamentem. Analiza radiowęglowa 14C „łopatki”, jak również sytuacja stratygraficzna znalezisk dowodzą, że wiążą się one ze starszym skupieniem $\mathrm{M} / 2013$.

Trzeci harpun (ryc. 9:2), który ma bezpośrednie oznaczenie wieku za pomocą analizy radiowęglowej 14C, został wydobyty na płyciźnie jeziornej w znacznym oddaleniu od brzegu, gdzie zapewne został zgubiony podczas połowów z łódki. Narzędzie to wiąże się z młodszym skupieniem M/2006 lub raczej z osadnictwem innych, jeszcze młodszych obozowisk maglemoskich położonych poza badanymi wykopami.

Harpuny mają formy typowe dla zespołów maglemoskich: a $-\mathrm{z}$ jednym zadziorem typu Gniewino (Nr 5/Nr 15) - według klasyfikacji J.G.D. Clarka (1936) i T. Galińskiego (2014a) - dwa egzemplarze o długości 16,8 cm i 17,2 cm (ryc. 9:2-3) oraz b - z kilkoma zadziorami typu Mullerup ( $\mathrm{Nr} 7 / \mathrm{Nr} 16)$ według tych klasyfikacji - okaz o długości 19,9 cm (ryc. 9:1).

Wspomniana już łopatka rogowa to przedmiot o długości $23 \mathrm{~cm}$ wykonany z poroża łosia i ozdobiony dwiema zygzakowatymi, równolegle biegnącymi liniami rytymi w poprzek uchwytu (ryc. 8). Funkcja okazu nie jest znana. Prawdopodobnie miał on związek z odprawianymi nad brzegiem jeziora obrzędami lub uprawianiem magii przez mieszkańców obozowiska.

\section{STANOWISKO W BOLKOWIE NA TLE OSADNICTWA POLUDNIOWO-ZACHODNIEJ STREFY BALTYKU}

W pierwszej połowie późnego okresu preborealnego, tj. ok. 9700-9400 BP, istniały w Bolkowie zespoły flixtońskie, które reprezentują najstarsze osadnictwo mezolityczne na Niżu Europejskim, nawiązujące bezpośrednio do miejscowych ugru- 
powań paleolitycznych z okresu oscylacji Friesland/najmłodszy dryas (skupienie w wykopie I/2010 i „zespół starszy” z badań D. Jankowskiej - Galiński, Jankowska 2006). Cechą charakterystyczną tych zespołów są duże i bardzo duże formy zbrojników, które wykonywane były z szerokich, regularnych wiórów stylu A. Pod względem typologicznym są to $\mathrm{w}$ zdecydowanej większości półtylczaki skośne, klasyfikowane formalnie jako typ Komornica oraz ostrza typu Vig. Towarzyszą im różne tylczaki i nieliczne trójkąty (Galiński, Jankowska 2006, ryc. 39-40).

Około 9400-9350 BP pojawiają się na stanowisku w Bolkowie zespoły Duvensienu klasycznego. Reprezentowane są przez liczne skupienia występujące w strefie brzegowej dawnego jeziora Krynickiego, badane w latach 2011-2013 (Galiński 2014a), a także przez ,zespół młodszy” z wcześniejszych badań Dobrochny Jankowskiej (Galiński, Jankowska 2006). Zbrojniki wykonywane były z drobnych wiórów i wiórków stylu $\mathrm{B}$ oraz z odłupków, i są znacznie mniejsze od narzędzi flixtońskich. Obok klasycznych półtylczaków typu Komornica znajdują się też liczne tylczaki, głównie typu Stawinoga i łukowe, oraz trójkąty równoramienne i nierównoboczne rozwartokątne o małym boku długim. Zespoły duwensejskie klasyczne mają pod każdym względem charakter zdecydowanie allochtoniczny, związany z różnymi ugrupowaniami określanymi wspólnym mianem epitardigraweckich strefy śródziemnomorskiej (Galiński 2002, s. 348 i n.). Wiele przesłanek wskazuje, że ich pojawienie się na stanowisku w Bolkowie wiąże się bezpośrednio z przybyciem tu określonej grupy społecznej z południa Europy. Oznacza to, że miejscowa ludność reprezentowana przez zespoły flixtońskie została zmuszona do opuszczenia tych ziem i wycofania się na północne obszary Niżu - na tereny tzw. Dogger Banku i południowej Skandynawii - gdzie przez cały okres preborelny rozwijała się tradycja kulturowa nawiązująca do miejscowego paleolitu. Osadnictwo duvensejskie na stanowisku w Bolkowie istniało nieprzerwanie przez ponad 500 lat. Najmłodsze oznaczenia radiowęglowe $14 \mathrm{C}$ odnoszące się do tych zespołów oscylują w granicach 8900-8800 BP i dokładnie korelują z ogólnym datowaniem końca III fazy osadnictwa wczesnych zespołów kompleksu duvensejskiego na całym obszarze Niżu Środkowoeuropejskiego (Galiński, 2002, s. 176). Młodsze zespoły tego ugrupowania nigdy nie występowały na stanowisku w Bolkowie.

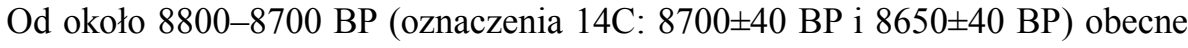
są tu wyłącznie zespoły kompleksu maglemoskiego. Wielki powrót potomków tradycji flixtońskiej w rejon jeziora Świdwie wiąże się z ekspansją terytorialną ugrupowań maglemoskich z obszarów dzisiejszej Danii i zalanego obecnie pomostu lądowego łączącego Jutlandię z Wielką Brytanią oraz na wyspy duńskie z Pomorzem Zachodnim. Szczegółowa analiza technologiczno-typologiczna najstarszego skupienia w Bolkowie wykazuje, że osadnictwo to ma silne konotacje z wczesnym Maglemosianem strefy jutlandzkiej. Świadczy o tym nietypowy dla zespołów klasycznych strefy bałtyckiej brak elementów technologiczno-typologicznych stylu C, bardzo niski udział grupy trójkątów oraz wysoki wskaźnik grupy tylczaków specjal- 
nych, w tym obecność takich charakterystycznych form, jak: jednozadziorce (ryc. 4:1), tylczaki rombowate (ryc. 4:2), ostrza Broxbourne (ryc. 4:5) czy ostrza typu Creswell (ryc. 4:9). Na tej podstawie można sądzić, że kierunek ekspansji łowców maglemoskich zasiedlających w początkach borealu basen jeziora Świdwie prowadził od terenów położonych u nasady Półwyspu Jutlandzkiego w kierunku wschodnim wzdłuż ówczesnego brzegu Morza Bałtyckiego. Jest wysoce prawdopodobne, że przybysze pochodzili z zalanego obecnie tzw. Dogger Banku. Uformowana tu najstarsza enklawa osadnicza obejmowała cały obszar dzisiejszej Puszczy Wkrzańskiej, tj. ziemie leżące pomiędzy środkową i dolną Wkrą (Ücker) na zachodzie a jeziorem Świdwie na wschodzie. W kierunku Odry osadnictwo to nie przekroczyło północnych skłonów morenowych Wału Stobniańskiego nad środkowym biegiem rzeki Gunicy (Galiński 2011, s. 117 i n.).

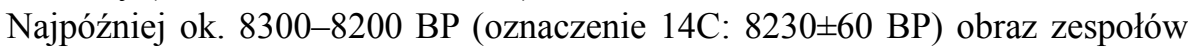
maglemoskich na stanowisku w Bolkowie ulega dość istotnej zmianie. Pod względem technologicznym i typologicznym przybierają one charakter klasycznych zespołów maglemoskich strefy bałtyckiej (skupienie M/2006). W produkcji narzędziowej znaczący udział mają elementy stylu $\mathrm{C}$, a bogata pod względem typologicznym grupa trójkątów - wśród których na szczególną uwagę zasługuje obecność dużych trójkątów rozwartokątnych o małym oku krótkim i podobnych okazów, lecz z pazurowatym wierzchołkiem (ryc. 7: 8-9) - zyskuje zdecydowaną przewagę nad tylczakami i półtylczakami. Zespoły te istniały przez ok. 400 lat. W początkach okresu atlantyckiego, tj. ok. 7900-7800 BP (oznaczenie radiowęglowe 14C: $7920 \pm 40 \mathrm{BP}$ ), w związku ze znaczącym podnoszeniem się poziomu wód w sąsiadujących ze stanowiskiem zbiornikach jeziornych i zalewaniem platformy terasy, obozowiska łowców mezolitycznych znikają stąd zupełnie. Jak dowodzi znalezisko harpuna kościanego typu Gniewino w strefie przybrzeżnej ówczesnego Jeziora Krynickiego (oznaczenie 14C: $7760 \pm 50 \mathrm{BP}$ ), obszar ten był dalej penetrowany przez łowców maglemoskich, jednak ich obozowiska znajdowały się na wyżej położonych i suchszych gruntach. Mogły to być na przykład południowe obrzeżenia dzisiejszego jeziora Świdwie, oddalone o prawie 1,5 km w kierunku wschodnim, gdzie na rozległej terasie piaszczystej zarejestrowano bogate ślady osadnictwa maglemoskiego z początków okresu atlantyckiego (stan. Bolków 2).

\section{BIBLIOGRAFIA}

Clark J.G.D.

1936 The Mesolithic Settlement of Northern Europe. Cambridge: Cambridge University Press.

Galiński T.

2002 Spoleczeństwa mezolityczne. Osadnictwo, gospodarka, kultura ludów towieckich w VIII-IV tysiacleciu p.n.e. na terenie Europy. Szczecin: Muzeum Narodowe. 
Galiński T.

2009 Badania paleolitu i mezolitu na Pomorzu Zachodnim w latach 1982-2006. W: M. Fudziński, H. Paner (red.), Aktualne problemy epoki kamienia na Pomorzu (s. 85-115). Gdańsk: Muzeum Archeologiczne w Gdańsku.

Galiński T. 2010 Łuk myśliwski z Bolkowa. Archeologia Żywa, 5,14.

Galiński T.

2011 Organizacja terytorialna osadnictwa łowców mezolitycznych. Studia na przykładzie obszaru rynny plejstoceńskiej dolnej Odry. Archeologia Polski, 46(1-2), s. 89-133.

Galiński T.

2014a Typological, chronological and cultural verification of Pleistocene and Holocene bone and antler harpoons and points from the southern Baltic zone. Przeglad Archeologiczny, 61, s. 93-143.

Galiński T.

2014b Obozowiska łowieckie ze schyłku preborealu w Bolkowie na Pomorzu Zachodnim. Archeologia Polski, 59(1-2), s. 79-120.

Galiński T., Jankowska D.

2006 Bolków 1. Stanowisko z końca paleolitu i początków mezolitu nad jeziorem Świdwie na Pomorzu Zachodnim. Materiały Zachodniopomorskie. Nowa Seria, II/III(1), s. 79-175.

Jankowska D.

$1980 \quad$ Z badań nad najstarszym osadnictwem w rejonie dolnej Odry. Materiaty Zachodniopomorskie, 26, s. 19-38.

Starkel L.

1977 Paleogeografia holocenu. Warszawa: Państwowe Wydawnictwo Naukowe.

\section{BOREAL BOLKÓW. \\ NEW STUDY OF THE MESOLITHIC CAMP ON ŚWIDWIE LAKE}

Sum mary

Late Paleolithic and early Mesolithic site in Bolków on Świdwie lake in Western Pomerania has been known in archaeological papers since the excavations led by D. Jankowska in the 1980s. (Galiński, Jankowska 2006, Fig. 1). Between 2006 and 2013 new large-scale excavations were conducted by the author within a platform of a terrace and coastal areas of a former lake (Fig. 2). As a result, rich, well-preserved remains of numerous hunting camps dating back to pre-Boreal and Boreal periods have been identified and studied, including hearths, storage pits and traces of huts, as well as an abundance of flint implements, or antler and animal bone, as well as wooden artefacts and tools.

The article concerns the issue of the Mesolithic settlement in Boreal period, which is related to Maglemose culture. It is represented by two large concentrations (Fig. 2). The older of the two, $\mathrm{M} / 2013$ covered an area of 140 square meters and consisted of three concentrations of dimensions 5.5 by $5.0 \mathrm{~m} ; 5.0$ by $3.5 \mathrm{~m}$ and 4.5 by $4.0 \mathrm{~m}$, about 3 to 5 meters from one another. The younger concentration $\mathrm{M} / 2006$ spread across a similar area and consisted of two oval concentration respec- 
tively of 4.0 by 3.0 and 3.5 by $3.0 \mathrm{~m}$ in diameter, about $2-3 \mathrm{~m}$ from each other. In Tables $1-3$ the typological characteristics of the cores and tools from both concentrations has been presented. The most typical forms of these assemblages have been illustrated in figures $4-5$. The older concentration $\mathrm{M} / 2013$ includes bone harpoons (Fig. 9:1,3) and an antler item decorated with incised ornament (Fig. 8).

Radiocarbon dating and hydrostratigraphy of the site have dated concentration M/2013 back to the beginning of Boreal period (about 8800/8700-8400 BP), while younger concentration $\mathrm{M} / 2006$ to late Boreal and the beginning of Atlantic periods (about 8200-7900 BP).

The appearance of Maglemosian hunters in Świdwie lake area was associated with territorial expansion of these groups from modern Denmark and recently flooded land bridge connecting Jutland with Great Britain and the Danish islands with Western Pomerania. A detailed technological and typological analysis of the oldest assemblage in Bolków (concentration M/2013) shows that this settlement strongly relates to the early Maglemose culture of the Jutland area. The oldest settlement enclave which had developed there encompassed the entire territory of modern Puszcza Wkrzańska, i.e. the area between the middle and lower Wkra (Ücker) River in the west and Lake Świdwie in the east. Towards the Oder River, the settlement did not exceed the middle course of the Gunica River.

At the latest around 8300/8200 BP the structure of Maglemose assemblages at Bolków site changed quite significantly (concentration $\mathrm{M} / 2006$ ). In terms of technology and typology they got the features the classic Maglemose assemblages of the Baltic area. These assemblages were then present for about 400 years. At the beginning of Atlantic period, i.e. about 7900/7800 BP, due to a significant rise in water levels in the lakes adjacent to the site and thus flooding of the terrace platform, Mesolithic hunters' camps completely disappeared from there. As evidenced by the bone harpoon of Gniewino type (Fig. 9:2), contemporary coastal area of Krynickie lake (14C: $7760 \pm 50$ BP) was still penetrated by Maglemose hunters, however, their camps were located in more elevated areas with drier soils. This could be, for example, the southern margin of modern Świdwie lake about $1.5 \mathrm{~km}$ eastwards, where there is a vast sandy terrace with rich traces of the Maglemose settlement dating back to the Atlantic period. 